\title{
Identifikasi Jenis Tepung Terigu Pada Roti Goreng Berdasarkan Fitur LBP dengan Menggunakan Jaringan Saraf Tiruan
}

\author{
Leonardo Chandra. B *1, Gasim ${ }^{2}$, Rusbandi ${ }^{3}$ \\ ${ }^{1,2,3}$ STMIK GI MDP, Jalan RajawaloNo. 14 Palembang, 0711-376400 \\ Jurusan Teknik Informatika, STMIK MDP, Palembang \\ e-mail: *11 leonardochandra@mhs.mdp.ac.id, ${ }^{2}$ gasim@mdp.ac.id, ${ }^{3}$ rusbandi@mdp.ac.id,
}

\begin{abstract}
Abstrak
Penelitian ini tentang mengidentifikasi jenis tepung terigu pada goreng dengan

menggunakan metode jaringan saraf tiruan. Jenis tepung terigu yang digunakan adalah kunci biru, sania, dan segitiga biru. Metode pengenalan yang digunakan adalah backpropagation . Hasil pengujian yang dilakukan menggunakan ukuran pixel $450 x 450 \mathrm{px}$, jarak potret sejauh \pm 20 $\mathrm{cm}$, resolusi kamera $16 \mathrm{MP}$, menggunakan data latih sebanyak 100 citra/jenis dan data uji sebanyak 80 citra/jenis serta dengan menggunakan ekstraksi ciri Local Binary Pattern maka didapatkan hasil berupa tingkat akurasi sebesar 68,57\%, presisi sebesar 53,33\% dan recall sebesar $54,47 \%$.
\end{abstract}

Kata kunci- Tepung Terigu, Local Binary Pattern, LBP, Jaringan Saraf Tiruan, Backpropagation

\begin{abstract}
This research is about identifying types of wheat flour in fyringgby using neural network methods. The types of wheat flour used are kunci biru, sania, and segitiga biru, The recognition method used is backpropagation. The result of the tests conducted using a pixel size of 450x450px , distance of portrait as far as $\pm 20 \mathrm{~cm}, 16 \mathrm{MP}$ camera resolution, using training data of 100 images/type and test data of 80/type images and usinLocal Binary Pattern feature extraction, the results obtained in the form of an accuracy level of 68,57\%, 53,33\% precision, and 54,47\% recall.
\end{abstract}

Keywords - Wheat Flour, Local Binary Pattern, LBP, Artificial Neural Networks, Backpropagation

\section{PENDAHULUAN}

$\mathrm{G}$ andum pertama kali ditemukan di daerah Timur Tengah sebelum tahun 9600 SM dan termasuk salah satu biji-bijian pertama yang ditanam oleh manusia secara besar- besaran. Seiring dengan pertumbuhan \& penyebaran populasi manusia, gandum juga berfungsi sebagai makanan pokok yang ikut menyebar ke seluruh penjuru dunia sehingga menyebabkan banyak varietas dan jenis gandum yang ada [1].

Tepung terigu merupakan bahan pokok dasar yang digunakan dalam pembuatan berbagai jenis makanan. Tepung terigu berasal dari biji gandum yang sudah diolah melalui proses penggilingan sehingga berubah bentuk menjadi serbuk atau butiran halus yang berwarna putih, karena tepung terigu berasal dari gandum maka tepung terigu termasuk kategori karbohidrat yang cukup tinggi. Tepung terigu memiliki gluten, dimana gluten ini adalah salah satu jenis protein 
yang memiliki peran untuk menentukan tingkat elastisitas dan kekenyalan pada suatu olahan makanan. Oleh karena itu tepung terigu terdiri dari 3 jenis yaitu tepung terigu yang memiliki kadang protein sedang, tepung terigu yang memiliki kadar proterin rendah dan tepung terigu yang memiliki kadar protein tinggi [2].

Roti merupakan salah satu jenis makanan dari hasil pengolahan tepung terigu. Dalam pembuatan roti biasanya menggunakan berbagai cara seperti digoreng, dikukus, dan lain-lain. Berdasarkan bahan yang dibutuhkan dan diolah sesuai dengan caranya maka akan menghasilkan roti yang baik, baik dari segi rasa serta aman untuk di konsumsi. Meskipu banyak sekali jenis tepung terigu yang dapat digunakan untuk pembuatan roti, setiap jenis tepung terigu akan dapat memberikan hasil yang berbeda.

Kualitas pada roti ditentukan oleh tekstur dimana tekstur tersebut berpengaruh pada jenis tepung terigu yang digunakan, seperti pada penelitian tentang penggunaan tepung terigu komposit dari terigu, pati sagu, dan tepung jagung dalam pembuatan roti tawar, yang memberikan pengaruh nyata terhadap perlakuan rasio komposisi tepung terigu, pati sagu, dan tepung jagung terhadap atribut tekstur roti [3].

Penelitian tentang daya serap air sebagai acuan untuk menentukan volume air dalam pembuatan adonan roti dari campuran tepung terigu dan tepung singkong. Pada penelitian ini menjelaskan bahwa tepung terigu memberikan stabilitas panas yang lebih tinggi dibanding tepung singkong. Pada campuran tepung terigu dan tepung singkong, makin tinggi porsi tepung singkong maka semakin rendah stabilitas panasnya sehingga semakin kecil daya serap airnya [4].

Penelitian tentang identification of wood defect based on LBP features, dalam penelitian ini mendeteksi mengenai kerusakan pada kayu dengan melakukan perbandingan metode antara gray level co-occurrence matrix (GLCM) dan local binary pattern (LBP). Hasil dari penelitian ini menunjukan bahwa tingkat akurasi yang di berikan LBP lebih besar daripada tingkat akurasi yang diberikan oleh GLCM yaitu sebesar 93,3\% dalam mengklasifikasikan jenis kecacatan pada kayu [5].

Penelitian tentang identifikasi jenis tepung terigu pada roti menggunakan jaringan saraf tiruan. Pada penelitian ini melakukan identifikasi pada roti berdasarkan resolusi kamera $12 \mathrm{MP}$, jarak potret $15 \mathrm{~cm}$, pemotongan terhadap citra sebesar 350x350 dan 600x600 pixel, menggunakan ekstraksi GLCM sebagai nilai input metode jaringan saraf tiruan (JST), sehingga menghasilkan tingkat akurasi sebesar 68,26 \% [2]. Penelitian tentang identifikasi citra tanda tangan menggunakan local binary pattern (LBP) pada smartphone berbasis android, penelitian ini menggunakan data latih sebanyak 500 sampel dengan rata-rata tingkat akurasi sebesar 80,8\% dan pengujian tertinggi sebesar $94 \%$ [6].

Berdasarkan penelitian terdahulu yang telah diuraikan pada paragraf-paragraf sebelumnya, fitur LBP dan metode jaringan saraf tiruan dapat digunakan untuk mengidentifikasi sebuah objek sehingga berpotensi dapat digunakan untuk membantu dalam sebuah penelitian, karena belum ada penelitian tentang mengidentifikasi jenis tepung terigu dengan menggunakan fitur LBP dan metode jaringan saraf tiruan. Objek yang digunakan adalah roti goreng, roti ini akan di potong dengan ukuran pixel sebesar $450 \mathrm{x} 450 \mathrm{px}$ dan jarak potret sejauh $\pm 20 \mathrm{~cm}$ dan menggunakan resolusi kamerea sebesar 16MP, maka berdasarkan hal tersebut penelitian ini penting dilakukan dengan tujuan untuk menerapkan metode jaringan saraf tiruan dan menggunakan ekstraksi fitur LBP, serta mengetahui tingkat akurasi dari hasil identifikasi jenis tepung terigu pada roti goreng.

Chandra B. et., al (Identifikasi Jenis Tepung Terigu Pada Roti Goreng Berdasarkan Fitur LBP dengan Menggunakan Jaringan Saraf Tiruan) 


\section{METODE PENELITIAN}

Berikut ini adalah tahapan jalannya penelitian yang dapat dilihat pada Gambar 1.

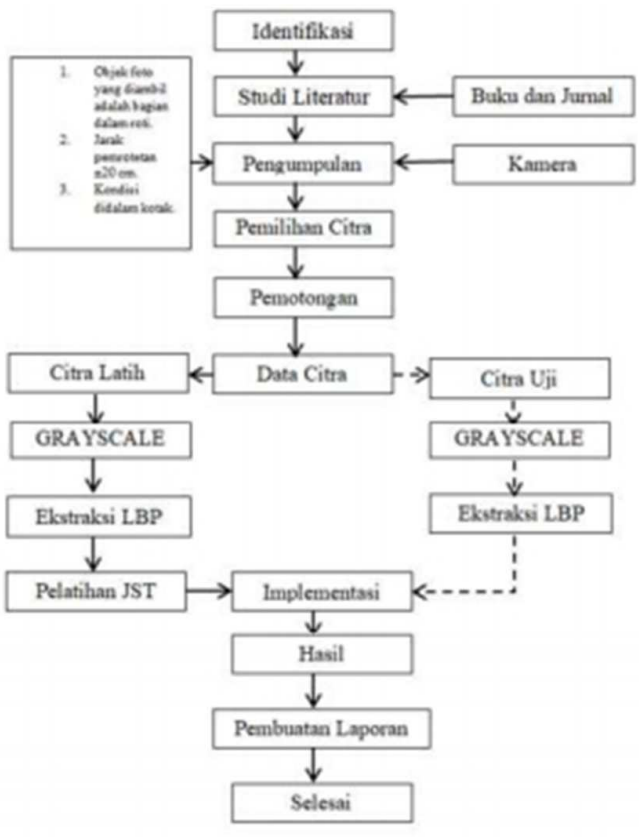

Gambar 1. Metodologi Penelitian

Penelitian ini dimulai dengan identifikasi masalah yang akan diselesaikan. Adapun masalah yang ditemukan adalah bagaimana menerapkan metode pengenalan JST dalam mengidentifikasi jenis tepung terigu pada roti goreng dengan menggunakan citra (foto). Masalah ini diselesaikan melalui studi literatur dan pustaka, pengumpulan data yang terdiri dari pembuatan bahan, pemotretan, pemilihan citra, pemotongan, pembagian data citra untuk citra latih dan citra uji, diubah kedalam grayscale, ektraksi LBP, pelatihan JST, implemantasi, diakhiri dengan pengujian hasil dan pembuatan laporan.

Studi literatur dilakukan untuk mendapatkan referensi dari penelitian terkait. Referensi yang digunakan bersumber dari jurnal nasional maupun internasional yang berhubungan dengan objek dan metode yang sudah pernah dilakukan, sehingga tidak menyebabkan terjadinya penelitian yang berulang. Studi pustaka dibutuhkan untuk mendapatkan teori-teori dasar yang akan digunakan pada penelitian ini.

Pada pengumpulan data, diawali dengan membuat roti goreng dengan menggunakan 3 jenis tepung terigu yang berbeda serta bahan lainnya yang dapat dilihat pada Gambar 2 .

Chandra B. et., al Identifikasi Jenis Tepung Terigu Pada Roti Goreng Berdasarkan Fitur LBP dengan Menggunakan Jaringan Saraf Tiruan 


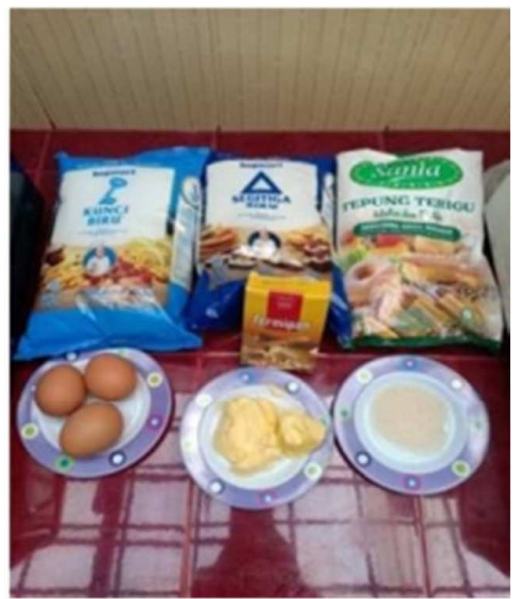

Gambar 2. Jenis Tepung Terigu

Roti goreng sudah dibuat dengan menggunakan 3 jenis tepung terigu yang berbeda, dipisahkan masing-masing rotinya dibuat menjadi Sembilan, yaitu 5 sampel untuk pelatihan dan 4 sampel untuk pengujian.

Setelah semua sampel tersedia selanjutnya dilakukan pemotretran terlebih dahulu pada permukaan dalam roti goreng yang dipotong horizontal seperti pemotongan hamburger yang dapat dilihat pada Gambar 3.

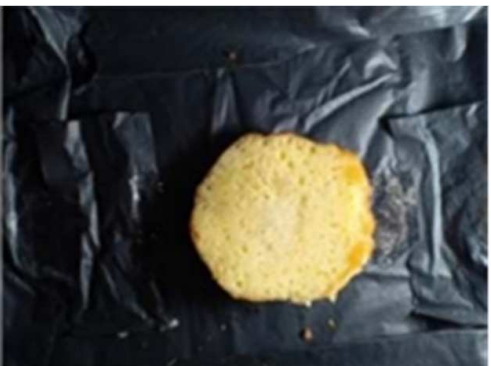

Gambar 3. Hasil dari Pemgambilan Gambar

Pemotretan dilakukan didalam kotak dengan menggunakan pencahyaan dari lampu dengan spesifikasi lampu adalah 15 watt. Pemotretan dilakukan tanpa menggunakan flash dari kamera. Kamera yang digunakan adalah kamera smartphone dengan resolusi kamera adalah $16 \mathrm{MP}$.

Pemotretan dilakukan dengan menggunakan jarak kurang lebih $20 \mathrm{~cm}$ seperti pada Gambar 4.

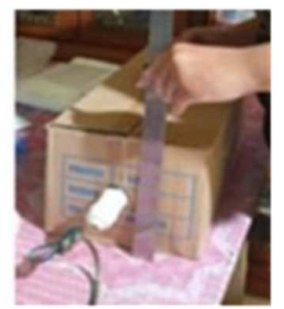

Gambar 4. Jarak Pengambilan Gambar

Chandra B. et., al (Identifikasi Jenis Tepung Terigu Pada Roti Goreng Berdasarkan Fitur LBP dengan Menggunakan Jaringan Saraf Tiruan) 
Pemotretan dilakukan beberapa kali untuk setiap sampel, hal ini dilakukan karena ketajaman citra tidak didapatkan pada seluruh bagian citra dari hasil pemotretan.

Setelah pemotretan dilakukan pemisahan citra dari hasil pemotretan. Hal ini dilakukan karena tidak semua hasil pemotretan citra merupakan citra yang diharapkan, yaitu citra yang tajam dan tidak kabur.

Selanjutnya untuk mengurangi latar di sekitar objek dengan ukuran pixel 450x450 piksel seperti pada Gambar 5 dan 6 [2].

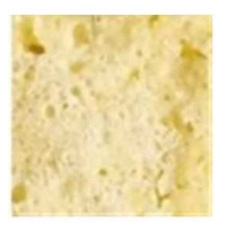

Gambar 5. Hasil pemotongan dengan gambar tidak blur

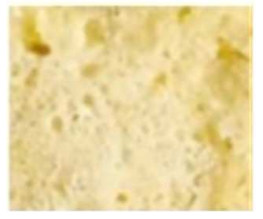

Gambar 6. Hasil pemotongan dengan gambar blur

Kumpulan citra yang berukuran 450x450 piksel dipilah lagi untuk dijadikan citra latih dan citra uji. Citra latih diambil dari sampel 1 sampai sampel 5 dan citra uji diambil dari sampel 6 sampai sampel 9. Hal ini dilakukan agar pengujian dilakukan pada sampel tidak digunakan pada pelatihan JST. Citra latih yang digunakan sebanyak 100 citra untuk setiap jenis dan citra uji sebanyak 80 citra untuk setiap jenis, sehingga total banyaknya citra latih adalah 300 citra dan banyaknya citra uji adalah 240 citra. Selanjutnya dilakukan ektraksi ciri pada 300 data latih untuk digunakan pada input JST.Pada tahapan ini, sebelum data citra dimasukan kedalam proses pelatihan dan pengujian, dilakukan proses pengubahan citra dari RGB menjadi grayscale agar dapat dilakukan proses ekstraksi fitur Local Binary Pattern (LBP).

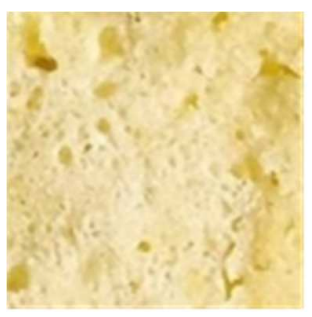

Gambar 7. Citra dalam bentuk RGB

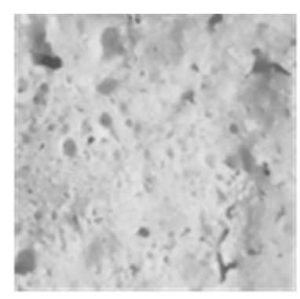

Gambar 8. Citra dalam bentuk grayscale

Metode LBP adalah salah satu metode yang digunakan untuk melakukan ekstraksi ciri pada suatu data citra grayscale [6]. Operasi LBP merupakan perbandingan 8 piksel disekelilingnya, dengan nilai piksel pusat yang berfungsi sebagai threshold seperti pada Gambar 8 [7]. 


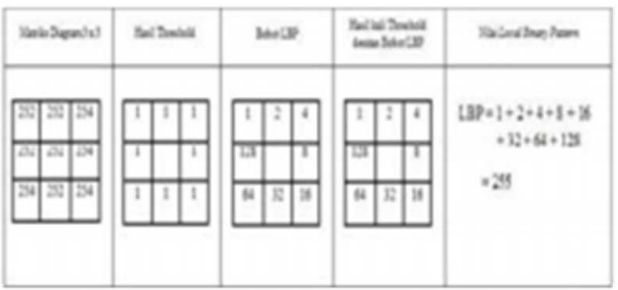

Gambar 8 Operator LBP

Berdasarkan nilai ambang batas Local Binary Pattern, maka nilai Local Binary Pattern dapat diperoleh dengan mengubah nilai-nilai tetangga menjadi 1 atau 0. Nilai 1 diperoleh jika piksel tetangga lebih besar atau sama dengan nilai pusat. Jika lebih kecil dari piksel pusat maka nilai tetangga diberi nilai 0 . Untuk setiap nilai piksel baru tersebut dikalikan dengan 2 . P mempunyai nilai 0 sampai dengan 7 . Nilai 0 dimulai dari pojok kiri atas dan dilanjutkan sesuai dengan arah jarum jam nilainya bertambah 1 . Persamaan LBP dapat dilihat pada persamaan 1 [12].

$$
L B P p, r=\sum_{p=0}^{P=1} s(I p, r-I c) 2^{P=1=p}
$$

Pada penelitian ini peneliti akan menggunakan ekstraksi fitur LBP yang ada di Matlab, sehingga peneliti tidak perlu menggunakan rumus secara manual untuk melakukan ekstraksi fitur LBP, hasil dari ekstraksi fitur LBP dapat dilihat pada Gambar 7 dan 8.

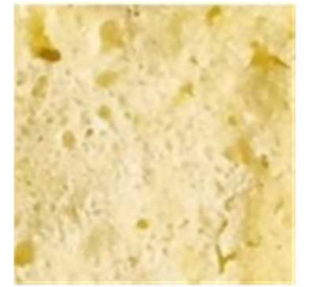

Gambar 7 Gambar tesktur roti yang belum

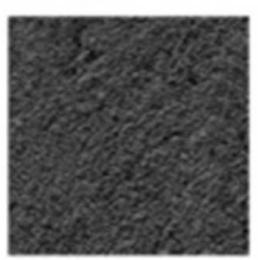

Gambar 8 Gambar tekstur roti yang diubah kedalam LBP 
Tabel 1 Target Hasil Output Penelitian

\begin{tabular}{|l|l|l|l|}
\hline Target & $\begin{array}{l}\text { Tepung } \\
\text { Terigu } \\
\text { Kunci } \\
\text { Biru(1- } \\
\text { 100) }\end{array}$ & $\begin{array}{l}\text { Tepung } \\
\text { Terigu } \\
\text { Sania(101- } \\
\text { 200) }\end{array}$ & $\begin{array}{l}\text { Tepung } \\
\text { Terigu } \\
\text { Segitiga } \\
\text { Biru(201- } \\
300)\end{array}$ \\
\hline $\begin{array}{l}\text { Tepung } \\
\text { Terigu } \\
\text { Kunci } \\
\text { Biru }\end{array}$ & 1 & 0 & 0 \\
\hline $\begin{array}{l}\text { Tepung } \\
\text { Terigu } \\
\text { Sania }\end{array}$ & 0 & 1 & 0 \\
\hline $\begin{array}{l}\text { Tepung } \\
\text { Terigu } \\
\text { Segitiga } \\
\text { Biru }\end{array}$ & 0 & 0 & 1 \\
\hline
\end{tabular}

Penelitian ini menggunakan model arsitektur JST yang dapat dilihat pada Gambar 9.

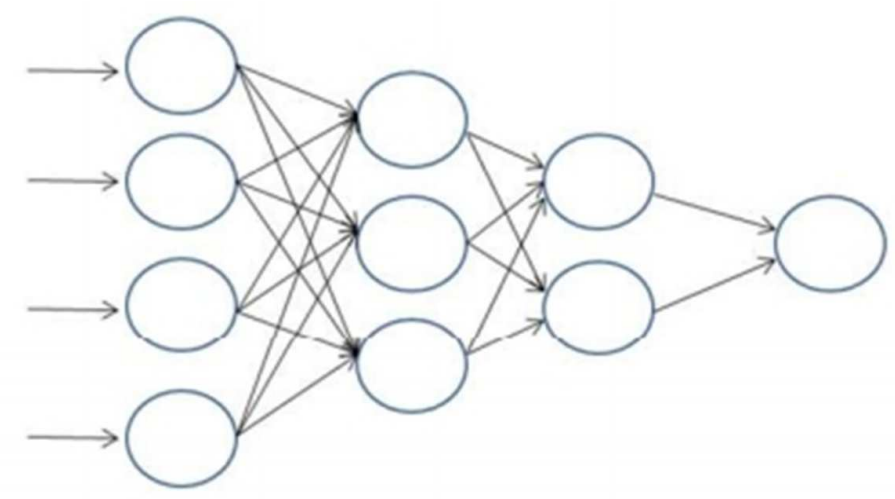

Gambar 9. Arsitekstur JST [11].

Pelatihan JST yang dimaksudkan agar semua data latih dapat dikenali oleh JST adalah dengan cara mengubah bobot nilai yang ada pada JST dengan menggunakan algorima propagasi balik. Pelatihan JST membutuhkan target yang berfungsi sebagai nilai output untuk tiap kolom input dari citra latih. Target yang dimaksud dapat dilihat pada Tabel 1.

Pada Tahapan ini, setelah cra latih dikenali dalam proses pelatihan, selanjutnya JST tersebut siap digunakan untuk pengujian terhadap citra uji.

Tahap pembentukan citra uji sama dengan tahapan pada pembentukan citra latih, mulai dari pemotretan hingga ekstrkasi ciri. Tahapan tersebut diawali dengan pemotongan citra menjadi 450x450 pixel, kemudian diubah menjadi grayscale lalu ektraksi ciri, dan terakhir diujikan pada

Chandra B. et., al Identifikasi Jenis Tepung Terigu Pada Roti Goreng Berdasarkan Fitur LBP dengan Menggunakan Jaringan Saraf Tiruan 
Vol. 1, No. 1, Oktober 2020, Hal. 90 - 101

JST yang sudah melalui tahap pelatihan. Dua tahap terakhir (ekstrkasi ciri dan diujikan pada JST) dilakukan dengan menggunakan aplikasi yang turut dikembangkan pada penelitian ini. Unrtuk membandingkan nilai dari tingkat akurasi dapat menggunakan rumus confusion matrix dapat dilihat pada persamaan (2), (3) dan (4).

$$
\begin{aligned}
& \text { Akurasi }=\frac{T P+T N}{T P+T N+F P+F N} \times 100 \% \\
& \text { Precision }=\frac{T P}{T P+F P} \times 100 \% \\
& \text { Recall }=\frac{T P}{T P+F N} \times 100 \%
\end{aligned}
$$

\section{HASIL DAN PEMBAHASAN}

\begin{tabular}{|c|c|c|c|c|c|c|c|c|c|c|c|}
\hline \multicolumn{12}{|c|}{ 要 } \\
\hline & 1 & 2 & 3 & 4 & 3 & 6 & , & 1 & 3 & 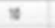 & $n$ \\
\hline 1, & ang & ast & $4=0$ & $\operatorname{asx}$ & Len & axis & 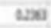 & $a w$ & Lax & $\cos$ & $2 x 0$ \\
\hline 2 & $\infty x$ & towe & ased & axe & cosed & aste & 1000 & $a x=$ & ann & $\cos$ & $a x$ \\
\hline 1 & ave & $2 x y$ & $0 x y$ & anse & toous & oxts & tant & ares & aneve & $\cos 4$ & axe \\
\hline 4 & axs & and & Cxes & $\operatorname{ses}$ & $\tan$ & axn? & atra & aros & 400 & 400 & an \\
\hline , & $\theta x$ & $\operatorname{tax}$ & $\Delta x$ & amm & $\operatorname{tane}$ & $a x$ & $\tan x$ & wee & ased & time & $\operatorname{axn}$ \\
\hline i & $\cos$ & sum & $0 x 00$ & aser & 2000 & arw & tons & axu & $a n v$ & cove & arma \\
\hline , & ase & 100 & oxx & axen & $\operatorname{tac} x$ & $\Delta=0$ & $\tan$ & tave & $\operatorname{axn}$ & $\cos$ & 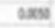 \\
\hline 1 & cose & atera & $\cos x$ & ase & $\tan$ & axsu & Anx & $\sin x$ & $2 \mathrm{~cm}$ & Grow & axt \\
\hline 1 & oxem & $\Delta x=$ & axes & asem & toose & $\Delta x y$ & $\tan$ & one & $\operatorname{axc}$ & $\cos 4$ & $a x e$ \\
\hline 10 & $\operatorname{cose}$ & asd & osst & ass & $\operatorname{tos}$ & aseow & tser & GSN & ase & tsen & assos \\
\hline ii & ase & thes & tam & ase & tent & asese & test & onst & Lev & $\cos \alpha$ & ases \\
\hline 0 & ase & tosen & cas & SASW & then & asen & asent & cma & stas & sowe & $\operatorname{asc}$ \\
\hline fu & osed & $\operatorname{sens}$ & $\cos \theta$ & ลองx & toe & 0,00 & tan & $0 \times 00$ & atser & towe & axs \\
\hline 4 & $\cos$ & 1000 & $\cos$ & ase & $\cos \theta$ & $\cos =$ & asca & tsece & and & $\cos x$ & asect \\
\hline 8 & seser & som & tant & toe & $\cos 4$ & asee & tese & $\operatorname{con} x$ & and & $\cos \theta$ & ase: \\
\hline \% & osem & asos & coses & ase & 1000 & сs:m & tien & axe & Stem & cous & axs \\
\hline (1) & $\cos$ & $\cos 4$ & oant & ase & towe & asez & $\operatorname{sen}$ & $\operatorname{cor}$ & $\operatorname{sen} x$ & $\cos$ & asea \\
\hline F & $\cos x$ & tuan & $\cos$ & ave & $\mathrm{tg}$ & ass & Ln: & $\tan$ & 200 & $\operatorname{CDO}$ & avs \\
\hline 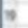 & wan & เล็ & $0 \times 00$ & $a b=$ & tons & $\operatorname{and}$ & 4050 & cosor & $\cos x$ & $\cos \theta$ & 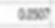 \\
\hline 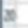 & eser & $2 \cos 4$ & bee & ane & tie & 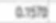 & thes & ose & aset & tset & ave? \\
\hline 5 & axen & Assi & oras & ASW & toms & ans & 4อง & uns & and & tons & asa \\
\hline 2 & exp & $20 x$ & ans & ase & ATSE & ave & Lra & $\cos \theta$ & 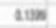 & Arat & $a x$ \\
\hline 3 & & tow & wet & ases & $\tan \theta$ & ass & toser & tore & axes & $\operatorname{cose}$ & AST \\
\hline
\end{tabular}

Pada proses ekstraksi ciri citra latih menghasil tabel latih (300 kolom x 59 baris) yang digunakan pada proses pelatihan JST dapat dilihat pada Gambar 10.

Gambar 10. Hasil Ekstraksi Fitur LBP

Chandra B. et., al (Identifikasi Jenis Tepung Terigu Pada Roti Goreng Berdasarkan Fitur LBP dengan Menggunakan Jaringan Saraf Tiruan) 


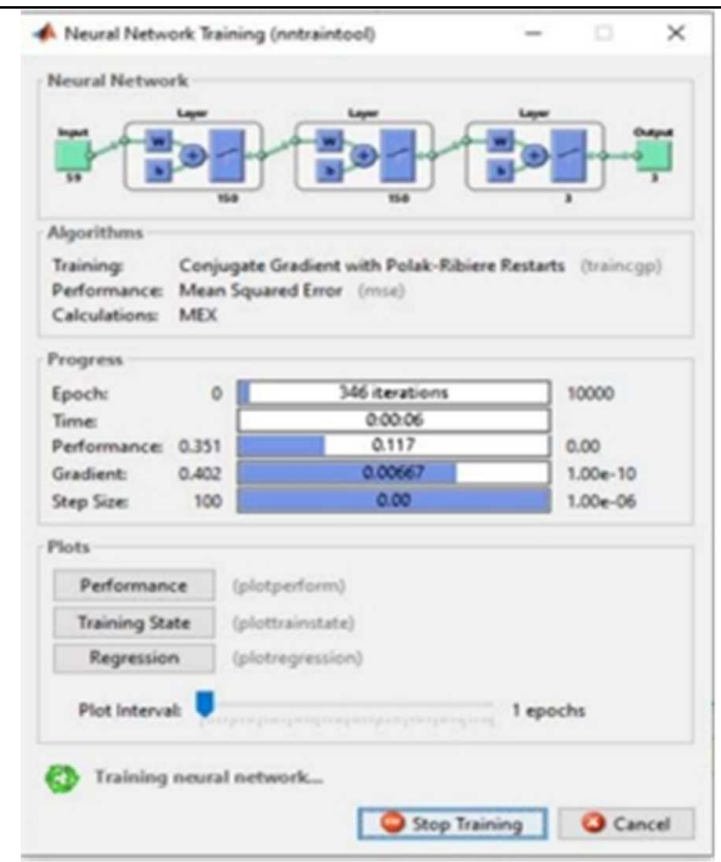

Gambar 11. Pelatihan Model JST

Tabel 2. Hasil Penentuan Hidden Layer

\begin{tabular}{|c|c|c|c|c|c|c|c|c|c|}
\hline \multirow[b]{2}{*}{ No } & \multicolumn{3}{|c|}{ Banyak Neuron } & \multirow[b]{2}{*}{$\begin{array}{c}\text { Training } \\
\mathrm{Ke}\end{array}$} & \multirow[b]{2}{*}{ MSE } & \multirow[b]{2}{*}{ Epoch } & \multirow[b]{2}{*}{ Time } & \multirow{2}{*}{$\begin{array}{l}\text { Data Latih } \\
\text { Dikenal }\end{array}$} & \multirow{2}{*}{$\begin{array}{l}\text { Data Uji } \\
\text { Dikenali }\end{array}$} \\
\hline & $\begin{array}{l}\text { Layer } \\
1\end{array}$ & $\begin{array}{l}\text { Layer } \\
2\end{array}$ & $\begin{array}{l}\text { Layer } \\
3\end{array}$ & & & & & & \\
\hline 1 & \multirow{5}{*}{15} & & & 1 & 0,01 & 4200 & 11 & 295 & 121 \\
\hline 2 & & & & 2 & 0,0067 & 5685 & 14 & 296 & 106 \\
\hline 3 & & & & 3 & 0,108 & 3385 & 9 & 167 & 76 \\
\hline 4 & & & & 4 & 0,0078 & 3001 & 10 & 296 & 117 \\
\hline 5 & & & & 5 & 0,0111 & 4623 & 12 & 294 & 132 \\
\hline 6 & \multirow{5}{*}{30} & & & 1 & 0,1156 & 3351 & 12 & 196 & 88 \\
\hline 7 & & & & 2 & 0,0033 & 6234 & 26 & 298 & 111 \\
\hline 8 & & & & 3 & 0,0055 & 5253 & 17 & 296 & 126 \\
\hline 9 & & & & 4 & 3,3883 & 5299 & 17 & 300 & 126 \\
\hline 10 & & & & 5 & 0,0067 & 5736 & 18 & 296 & 124 \\
\hline 11 & \multirow{5}{*}{45} & & & 1 & 0,0022 & 5122 & 20 & 298 & 125 \\
\hline 12 & & & & 2 & 0,0044 & 3364 & 14 & 297 & 110 \\
\hline 13 & & & & 3 & 0,0056 & 4775 & 20 & 297 & 116 \\
\hline 14 & & & & 4 & 0,0034 & 3352 & 12 & 298 & 125 \\
\hline 15 & & & & 5 & 0,0044 & 5345 & 20 & 298 & 111 \\
\hline 51 & \multirow{6}{*}{15} & \multirow{5}{*}{15} & & 1 & 2,4183 & 7614 & 26 & 300 & 129 \\
\hline 52 & & & & 2 & 0,0056 & 4943 & 16 & 296 & 130 \\
\hline 53 & & & & 3 & 0,0178 & 2885 & 10 & 291 & 129 \\
\hline 54 & & & & 4 & 0,0278 & 1791 & 6 & 284 & 110 \\
\hline 55 & & & & 5 & 0,0078 & 3416 & 11 & 296 & 124 \\
\hline 56 & & 30 & & 1 & 0,0111 & 3408 & 13 & 294 & 105 \\
\hline
\end{tabular}

Chandra B. et., al Identifikasi Jenis Tepung Terigu Pada Roti Goreng Berdasarkan Fitur LBP dengan Menggunakan Jaringan Saraf Tiruan 
Vol. 1, No. 1, Oktober 2020, Hal. 90 - 101

\begin{tabular}{|c|c|c|c|c|c|c|c|c|c|}
\hline 57 & & & & 2 & 0,0078 & 6172 & 21 & 296 & 112 \\
\hline 66 & \multirow{15}{*}{30} & \multirow{5}{*}{15} & & 1 & 0,0022 & 3844 & 16 & 299 & 118 \\
\hline 67 & & & & 2 & 0,0033 & 6144 & 24 & 298 & 110 \\
\hline 68 & & & & 3 & 0,0068 & 3689 & 14 & 296 & 124 \\
\hline 69 & & & & 4 & 0,0089 & 4086 & 16 & 296 & 125 \\
\hline 70 & & & & 5 & 0,1259 & 750 & 3 & 191 & 75 \\
\hline 71 & & \multirow{5}{*}{15} & & 1 & 0,1156 & 1519 & 7 & 197 & 94 \\
\hline 72 & & & & 2 & 7,7322 & 2854 & 13 & 300 & 112 \\
\hline 73 & & & & 3 & 0,0045 & 1798 & 8 & 298 & 123 \\
\hline 74 & & & & 4 & 0,12 & 1668 & 8 & 197 & 82 \\
\hline 75 & & & & 5 & 0,0066 & 1755 & 7 & 297 & 131 \\
\hline 76 & & \multirow{5}{*}{45} & & 1 & 0,0022 & 2044 & 11 & 299 & 125 \\
\hline 77 & & & & 2 & 0,0044 & 1700 & 9 & 298 & 135 \\
\hline 78 & & & & 3 & 0,01 & 1609 & 8 & 295 & 119 \\
\hline 79 & & & & 4 & 0,0022 & 2271 & 12 & 299 & 118 \\
\hline 80 & & & & 5 & 0,0133 & 2614 & 14 & 291 & 124 \\
\hline 81 & \multirow{8}{*}{45} & \multirow{5}{*}{15} & & 1 & 2,9202 & 2532 & 13 & 300 & 132 \\
\hline 82 & & & & 2 & 0,0233 & 2364 & 11 & 286 & 122 \\
\hline 83 & & & & 3 & 0,0022 & 3535 & 18 & 299 & 123 \\
\hline 84 & & & & 4 & 0,0102 & 2509 & 12 & 295 & 125 \\
\hline 85 & & & & 5 & 0,0123 & 1737 & 8 & 292 & 122 \\
\hline 86 & & \multirow{3}{*}{30} & & 1 & 0,0022 & 2466 & 13 & 299 & 128 \\
\hline 87 & & & & 2 & 0,0078 & 2740 & 15 & 295 & 124 \\
\hline 88 & & & & 3 & 0,0056 & 1399 & 8 & 297 & 123 \\
\hline 111 & \multirow{9}{*}{30} & \multirow{9}{*}{30} & \multirow{5}{*}{15} & 1 & 1,3863 & 3140 & 17 & 300 & 139 \\
\hline 112 & & & & 2 & 1,6518 & 3244 & 19 & 300 & 127 \\
\hline 113 & & & & 3 & 6,548 & 2027 & 11 & 300 & 115 \\
\hline 114 & & & & 4 & 0,0133 & 855 & 5 & 294 & 127 \\
\hline 115 & & & & 5 & 0,0044 & 3214 & 18 & 298 & 115 \\
\hline 116 & & & \multirow{4}{*}{30} & 1 & 7,009 & 2510 & 15 & 300 & 123 \\
\hline 117 & & & & 2 & 0,0111 & 2553 & 14 & 295 & 118 \\
\hline 118 & & & & 3 & 0,1189 & 914 & 5 & 195 & 98 \\
\hline 119 & & & & 4 & 8,0416 & 914 & 5 & 300 & 118 \\
\hline
\end{tabular}

Hidden layer 1 yang terpilih

Kombinasi Hidden layer 1 pilihan dengan hidden

layer 2 yang terpilih JST yang terpilih dengan hasil yang terbaik

Gambar 11 menunjukan proses training (pelatihan) JST. Hasil ini dapat dilihat pada Tabel 2 yang berisi tentang penentuan hidden layer berdasarkan banyaknya data uji yang dikenali.

Berdasarkan Tabel 2 dengan jumlah data latih 100/jenis dan data uji 80/jenis, menghasilkan sebuah data yaitu warna hijau tua merupakan hasil dari 1 hidden layeri yang memberikan hasil pengenalan pada data uji yang tinggi, selanjutnya warna hijau muda

Chandra B. et., al (Identifikasi Jenis Tepung Terigu Pada Roti Goreng Berdasarkan Fitur LBP dengan Menggunakan Jaringan Saraf Tiruan) 
merupakan 2 hidden layer yang memberikan hasil terbaik dalam pengenalan data uji, dan yang terkahir warna biru merupak 3 hidden layeri yang memberikan hasil maksimal dari pengenalan data uji.

Untuk penentuan hasil pengujian terhadap arsitektur JST, dilakukan perhitungan dengan menggunakan confusion matrix untuk mendapatkan hasil recall, precision, dan accuracy.

Tabel 3 Hasil Pengujian JST Dengan Banyak

Data Uji 80/jenis

\begin{tabular}{|r|l|r|r|r|}
\hline & \multicolumn{4}{|c|}{ Target } \\
\hline \multirow{4}{*}{ Output } & Jenis Tepung Terigu & Kunci Biru & Sani & Segitiga Biru \\
\cline { 2 - 5 } & Kunci Biru & 51 & 19 & 10 \\
\cline { 2 - 5 } & Sania & 40 & 39 & 1 \\
\cline { 2 - 5 } & Segitiga Biru & 30 & 12 & 38 \\
\hline \multicolumn{2}{|c|}{ Jumlah } & 121 & 70 & 49 \\
\hline
\end{tabular}

Pada Tabel 3 menunjukan hasil dari pengujian jenis tepung terigu pada model JST dengan jumlah data latih sebanyak 80 citra untuk setiap jenis. Kemudian dilakukan perhitungan untuk mendapatkan tingkat akurasi pengenalan jenis tepung terigu terhadap data uji dengan menggunakan confusion matrix pada Tabel 3.

Tabel 4 Hasil Perhitungan

Confussion Matrix Pada Data Uji

\begin{tabular}{|l|c|c|c|c|c|c|c|}
\hline & \multirow{2}{*}{ TP } & \multirow{2}{*}{ FP } & \multirow{2}{*}{ FN } & \multirow{2}{*}{ TN } & \multicolumn{4}{|c|}{ Hasil \% } \\
\cline { 6 - 9 } & & & & & Accuracy & Precision & Recall \\
\hline Kunci Biru & 51 & 29 & 70 & 90 & 58,75 & 63,75 & 42,15 \\
\hline Sania & 30 & 41 & 31 & 129 & 76 & 48,75 & 55,71 \\
\hline Segitiga Biru & 38 & 42 & 11 & 139 & 76,96 & 47,5 & 77,55 \\
\hline \multicolumn{3}{|c}{ Rata-rata } & & 68,57 & 53,33 & 58,47 \\
\hline
\end{tabular}

Pada Tabel 4 menunjukan hasil perhitungan dengan confusion matrix pada proses pengujian terhadap model JST untuk mengenali 3 jenis tepung terigu pada roti goreng dengan banyak data latih 100 citra/jenis dan data uji 80/jenis. Didapatkan hasil perhitungan dengan ratarata akurasi sebesar $68,57 \%$, rata-rata presisi sebesar 53,33\% dan rata-rata recall sebesar 58,47\%.

\section{KESIMPULAN}

Dari Hasil penelitian penelitian dan pembahasan yang sudah dilakukan, dapat disimpulkan bahwa hasil pengujian yang telah dilakukan dengan menggunakan kamera dengan resolusi 16MP, jarak potret sejauh $\pm 20 \mathrm{~cm}$, citra pemotongan sebesar 450x450px dan menggunakan data latih sebanyak 100citra/jenis dan data uji sebanyak 80 citra/jenis serta dengan menggunakan ekstraksi fitur LBP dan metode jaringan saraf tiruan didapatkan sebuah hasil bahwa pengenalan jenis tepung terigu pada roti goreng dengan menggunakan neuron sebanyak 30 neuron pada layer1, 30 neuron pada layer2 dan 15 neuron pada layer3 memberikan hasil yang terbaik dalam pengenalan data uji dibandingkan jumlah neuron yang lain pada 2.

Hasil terbaik yang diperoleh pada pengenalan jenis tepung terigu pada roti goreng dengan menggunakan banyak data latih sebanyak 300 citra memberikan hasil pengenalan sebanyak 300

Chandra B. et., al Identifikasi Jenis Tepung Terigu Pada Roti Goreng Berdasarkan Fitur LBP dengan Menggunakan Jaringan Saraf Tiruan 
citra dan menggunakan data uji sebanyak 240 citra memberikan hasil pengenalan sebanyak 139 citra. Hasil pengujian dengan menggunakan confusion matrix yang dapat dilihat pada Tabel 4 memberikan nilai rata-rata untuk akurasi sebesar $68,75 \%$, untuk presisi sebesar $53,33 \%$ dan untuk recall sebesar $58,57 \%$.

Berbeda dengan penelitian terdahulu yang menggunakan objek yang sama yaitu roti goreng dengan menggunakan ekstraksi fitur GLCM dan metode jaringan saraf tiruan. Ternyata hasilnya berbeda pada penelitian ini yaitu dengan menggunakan ekstraksi fitur LBP dan metode jaringan saraf tiruan.

Dari penelitian yang telah dilakukan, penulis memberikan saran untuk penelitian selanjutnya sebagai berikut:Penggunaan metode yang berbeda untuk meningkatkan kualitas citra digital khususnya pada peningkatan kontras citra.Penelitian selanjutnya disarankan pada proses pengujian dilakukan dengan menggunakan data uji yang berbeda dari penelitian.

\section{SARAN}

Dari penelitian yang telah dilakukan, penulis memberikan saran untuk penelitian selanjutnya sebagai berikut:

1. Penggunaan metode yang berbeda untuk mendapatkan hasil ciri yang lebih baik terhadap citra latih dan citra uji yang mungkin akan menghasilkan hasil yang lebih baik dari penelitian yang sudah dilakukan khususnya dalam pengenalan jenis tepung terigu pada roti goreng.

2. Mengubah ukuran resolusi kamera, jarak potret, ukuran untuk pemotongan citra serta jumlah data baik untuk data latih dan data uji yang akan digunakan.

\section{DAFTAR PUSTAKA}

[1] T. Terigu, "http://www.bogasari.com/product/tepung-terigu," PT. Bogasari, [Online]. Available: http://www.bogasari.com. [Accessed 10 June 2020].

[2] M. Yusuf and D. Juliansah, "Identifikasi Jenis Tepung Terigu Pada Roti," STMIK GLoba Informatika MDP, Palembang, 2019.

[3] A. Rahmah, . F. Hamzah and R. , "Penggunaan Tepung Komposit dari Terigu, Pati Sagu, dan Tepung Jagung dalam Pembuatan Roti Tawar," JOM FAPERTA, vol. 4, no. 1, 2017.

[4] R. Rauf and D. Sabrini, "Daya Serap Air sebagai Acuan untuk Menentukan Volume dalam Pembuatan Adonan Roti dari Campuran Tepung Terigu dan Tepung Singkong," AGRITECH, vol. 35, no. 3, 2015.

[5] Y. Z. d. Xiang, "Identification of Wood Defects Based on LBP Features," in IEEE Xplore, 2016.

[6] R. \&. B. S. A. T. Marcelino, "Apllication for Identifying Classical Surakarta Batik Patterns (APECOBA) Based on Android with the LBP Method," Jurnal Ilmiah Teknologi dan Informasi, vol. 8, no. 1, pp. 34-41, 2019.

[7] N. B. M. \&. P. E. I. Hayaty, "Penerapan Algoritma Local Binary Pattern untuk Pengenalan Pola Sidik Jari," Jurnal Sustainable, vol. 6, no. 2, pp. 74-79, 2017.

[8] C. H. M. B. R. \&. S. N. Aditya, "Batik Classification Using Neural Network with Gray Level CoOccurrence Matrix and Statistical Color Feature Extraction.," in Internasional Conference on Information, Communication Technology and System (ICTS), 2015.

[9] R. S. J. Y. \&. P. I. Amat, "Implementasi Metode Local Binary Patterns untuk Pengenalan Pola Huruf Hiragana dan Katakana pada Smartphone.," Jurnal Ilmu Teknologi Informasi, vol. 15, no. 2, pp. 162-172, 2017.

Chandra B. et., al (Identifikasi Jenis Tepung Terigu Pada Roti Goreng Berdasarkan Fitur LBP dengan Menggunakan Jaringan Saraf Tiruan) 
[10] I. N. A. \&. F. Fathurrahman, "Identifikasi Kematangan Mentimun Berbasis Citra Digital menggunakan Jaringan Saraf Tiruan Backpropagation.," Jurnal Informatika dan Teknologi, vol. 2, no. 1, 2019.

[11] T. M. E. \&. S. V. Sutojo, Kecerdasan Buatan, Yogyakarta: Andi Offset, 2011.

[12] M. E. Al Rivan and S. Devella, "PENGENALAN IRIS MENGGUNAKAN FITUR LOCAL BINARY PATTERN DAN RBF CLASSIFIER," Simetris, vol. 11, no. 1, pp. 97-106, 2020.

Chandra B. et., al Identifikasi Jenis Tepung Terigu Pada Roti Goreng Berdasarkan Fitur LBP dengan Menggunakan Jaringan Saraf Tiruan 